\title{
Biomechanical evaluation of two extracapsular techniques for cranial cruciate ligament reconstruction in cadaver dogs
}

\author{
Avaliação biomecânica de duas técnicas extracapsulares para \\ reconstrução do ligamento cruzado cranial em cadáveres de cães
}

\author{
Sam Goldy Shoyama Oda ${ }^{1}$; Alexandre Navarro Alves Souza ${ }^{2}$; \\ Cesar Augusto Martins Pereira ${ }^{3}$; Andrés Sebastian Aristizabal Escobar ${ }^{1}$; \\ Angelica Cecilia Tartarunas²; Julia Maria Matera ${ }^{4 *}$
}

\begin{abstract}
Cranial cruciate ligament rupture (CCLR) is one of the most important orthopedic conditions in dogs, leading to joint instability, pain, osteoarthritis and eventually to meniscal injuries. Several surgical techniques have been described to reestablish joint stability following CCLR, including extracapsular procedures. This study compared the biomechanical effects of two extracapsular stabilization techniques (lateral fabello-tibial suture - LFTS, and modified retinacular imbrication technique - MRIT) using nylon leader line following experimental CCLR in cadaver dogs. Twenty canine cadaveric stifles were used. Joint stiffness, cranial and caudal tibial displacement were evaluated in 4 different experimental scenarios: intact stifle, stifle with CCLR, CCLR treated with lateral fabello-tibial suture (LFTS), and CCLR treated with modified retinacular imbrication technique (MRIT). Results: Mean cranial tibial displacement increased progressively from intact to MRIT, LFTS and CCRL stifles. MRIT resulted in less caudal drawer motion than LFTS. Joint stiffness did not differ significantly between LFTS and MRIT treated stifles. Conclusion: LFTS and MRIT increase joint stability but MRIT is more effective; however none of the techniques studied was able to restore original intact stifle stiffness. Clinical implications of the results presented remain to be determined but kinetic gait analysis studies are warranted to determine whether this biomechanical advantage translates into improved hind limb function in dogs.
\end{abstract}

Key words: Biomechanics. Cranial cruciate ligament. Dogs. Fabellar suture. Stifle.

\section{Resumo}

A ruptura do ligamento cruzado cranial (RLCCr) é uma das principais afecções ortopédicas em cães e resulta na instabilidade do joelho, dor, desenvolvimento de osteoartrose, podendo também causar lesão de menisco. Com o intuito de restabelecer a estabilidade da articulação, muitas técnicas são utilizadas, dentre elas, as extracapsulares. O objetivo do presente trabalho foi realizar a avaliação biomecânica de duas dessas técnicas em 20 joelhos de cadáveres de cães utilizando-se fio de náilon leader line. Nestas peças foram avaliados a rigidez articular e o deslocamento tanto cranial quanto caudal da tíbia em quatro situações distintas: joelho íntegro; joelho com RLCCr e sutura fabelo-tibial lateral (SFTL);

\footnotetext{
${ }^{1}$ Discentes do Programa de Pós-Graduação em Clínica Cirúrgica Veterinária da Faculdade de Medicina Veterinária e Zootecnia, Universidade de São Paulo, FMVZ/USP, São Paulo, SP, Brasil. E-mail: sgoda@superig.com.br; aristis318@hotmail.com

${ }^{2}$ Pós-Doutorando, Departamento de Cirurgia, FMVZ/USP, São Paulo, SP, Brasil. E-mail: telha68@yahoo.com.br; angeltat@ gmail.com

${ }^{3}$ Tecnólogo, Laboratório de Biomecânica LIM-41 do Instituto de Ortopedia e Traumatologia do Hospital das Clinicas Faculdade de Medicina, Universidade de São Paulo, FM/USP, São Paulo, SP, Brasil. E-mail: cesaramp@usp.br

${ }^{4}$ Prof $^{\text {a }}$, Departamento de Cirurgia, FMVZ/USP, São Paulo, SP, Brasil. E-mail: materajm@usp.br

* Author for correspondence
} 
joelho com RLCCr e sutura fabelo-tibial lateral e medial (SFTLM); e por fim, o joelho com RLCCr sem as técnicas de estabilização. Houve diferença no deslocamento cranial entre todas as situações, sendo em ordem crescente, o joelho integro, com SFTLM, com SFTL e por fim, o joelho com RLCCr não estabilizado. Na comparação da presença de movimento de gaveta caudal a técnica de SFTLM apresentou menor deslocamento que a técnica de SFTL. Com relação à rigidez tanto cranial quanto caudal, as duas técnicas não apresentaram diferença. As duas técnicas testadas diminuem a instabilidade do joelho, sendo a SFTLM mais efetiva, e nenhuma delas restaurou a rigidez articular de um joelho íntegro. As implicações clínicas dos resultados apresentados ainda precisam ser determinadas, mas um estudo clínico com avaliação cinética da locomoção pode esclarecer se as diferenças biomecânicas encontradas entre estas duas técnicas são relevantes para a função locomotora dos cães.

Palavras-chave: Biomecânica. Cães. Joelho. Ligamento cruzado cranial. Sutura fabelo-tibial.

\section{Introduction}

The cranial cruciate ligament (CCL) has two functional components, a craniomedial (CMB) and a caudolateral band (CLB) (VASSEUR, 2003). The CCL is partially tensed and only the CMB component is loaded during knee flexion; however, both components are under tension and functionally active during extension (LEOPIZZI, 1998). The CCL limits cranial drawer motion and limb hyperextension, as well as inward rotation of the tibia and excessive valgus/varus motion during knee flexion (VASSEUR, 2003).

Stifle instability due to CCL rupture (CCLR) is one of the most common causes of hind limb pain and lameness in dogs; also, treatment of this condition has significant financial impacts (WILKE et al., 2005). Several techniques and materials have been employed for correction of CCLR and associated joint instability, and may be used in isolation or combined. Extracapsular procedures such as fabellotibial sutures have gained popularity due to low cost and ease of execution (WILKE et al., 2005; SNOW et al., 2010; CABANO et al., 2011). Fabellotibial sutures can be performed with a wide range of suture materials, including nylon leader line (BURGESS et al., 2010; CHOATE et al., 2013).

The CCL is anatomically and functionally complex and, despite the wide availability of techniques, consistent evidence of return to previous levels of function following CCLR repair is still lacking (ARAGON; BUDSBERG, 2005).
Similarly, biomechanical studies have failed to confirm the ability of different techniques to fully restore normal stifle function in dogs (BURGESS et al., 2010; CHOATE et al., 2013; D’AMICO et al., 2013).

This study compared the biomechanical effects of two extracapsular stabilization techniques (lateral fabellotibial suture - LFTS, and modified retinacular imbrication technique - MRIT) using nylon leader line following experimental CCLR in cadaver dogs. The purpose of this study was to compare the well-established LFTS stabilization technique with MRIT, using biomechanical parameters to determine whether the inclusion of the medial suture would provide additional stability to the operated joint.

\section{Materials and Methods}

\section{Sample}

Twenty intact canine cadaveric stifles collected from dogs weighing between 20 and $30 \mathrm{~kg}$. Procedures: Both cadaveric pelvic limbs were disarticulated at the hip joint, wrapped in plastic and soaked in saline solution. Specimens were stored frozen at $-20^{\circ} \mathrm{C}$ and thawed at room temperature immediately prior to biomechanical testing. Hind limb muscles were dissected away; the joint capsule and pericapsular muscular attachments were kept intact. Cadaveric stifles were submitted to four consecutive trials in four different scenarios, as follows: intact stifle (CCL group); CCLR stifle 
treated with lateral fabello-tibial suture (LFTS group); CLLR stifle treated with the modified retinacular imbrication technique (MRIT group) and untreated CCLR stifle (CCLR group). Intact stifles served as their own controls in this study.

\section{Surgical technique}

1. Arthrotomy. Lateral parapatellar arthrotomy was performed and the joint space and intraarticular structures inspected for signs of joint disease. Joints suspected of disease were discarded. The CCL was carefully transected and the capsular incision closed with 3-0 polyglactin 910 (Vicryl $^{\circledR}$ ) in a simple interrupted fashion. Fascial imbrication was performed with 2-0 mononylon suture.

2. Lateral fabello-tibial suture. Following palpation of the stifle and location of the lateral fabella, a nylon suture loop was placed around this structure in a cranial-to-caudal direction; a J needle was used to anchor the suture line to the fabellofemoral ligament. A tunnel was then drilled across the tibial tuberosity in a lateral-to-medial direction, caudal and distal to the insertion of the patellar ligament. The distal end of the suture was introduced into the drill hole avoiding an " 8 " configuration; a straight Kelly forceps was then used to pass the suture underneath the patellar ligament in a lateroto-medial direction and towards the proximal end of the suture (close to the hole in the tibial tuberosity). With the limb in the anatomical position, the tibia was pulled caudally relative to the femur to prevent cranial drawer motion and mild tibial external rotation produced. Finally, the suture was tied with the knot placed close to the medial aspect of the hole in the tibial tuberosity.

3. Modified retinacular imbrication technique. The same technique was used, however with suture loops placed around the lateral and medial fabellae. The hole in the tibial tuberosity was wide enough to accommodate two sutures. Knots were tied in the same way laterally and medially.
4. Suture material and knots. Sutures were performed using Mason Hard Type Nylon Monofilament Leader Line (60 lb or $27 \mathrm{~kg} / \mathrm{test}$ ). A digital dynamometer ${ }^{4}$ was used to keep the line under tension of approximately 100 Newtons (N) prior to knot tying with a needle holder.

\section{Biomechanical testings}

Biomechanical testings were performed at the Biomechanics Laboratory of the Institute of Orthopedics \& Traumatology, School of Medicine, University of São Paulo (LIM-41; IOT-HC-USP).

Biomechanical tests were performed using a Kratos universal testing machine (KRATOS 5002) with a load cell of $100 \mathrm{kgf}$ connected to a computer equipped with data acquisition system. The femur was mounted onto the upper hydraulic arm and the tibia onto the lower platform of the kratos machine by means of cylindrical metallic grips and radially distributed bolts (perpendicular to the long bone diaphysis). The femoral end of the construct was stationary. However, the tibia was kept movable to allow inward/outward rotation and valgus/varus motion, as well as movement of the tibia towards and away from the femur during biomechanical testing. Stifle flexion $\left(135^{\circ}\right)$ was maintained throughout the testing procedure.

Cranial and caudal part-load $(50 \mathrm{~N})$ translation trials were then performed to locate the inflexion point on graphs generated by the software. The inflexion point was described as the point in time when stabilizing structures of the stifle were under the least tension and was taken as the starting point for the remaining biomechanical tests.

Distance from the tibia, angle of rotation and initial pachymetry were determined from the inflexion point and used as references for repositioning of the specimen as necessary. The distance from the tibia was measured using a caliper ${ }^{5}$ and used as reference for accurate repositioning of the distal grip; angle or rotation and initial pachymetry measurements were used for accurate repositioning of the proximal grip. 
Three alternating cranial and caudal drawer loading cycles $(100 \mathrm{~N})$ were performed at a constant velocity of $20 \mathrm{~mm} /$ minute. Joint stiffness and cranial/caudal displacement of the tibia relative to the femoral condyles were evaluated.

\section{Statistical analysis}

Statistical analyses were performed using software (Statistical Analysis System). Normality of data was investigated and homogeneity of variance compared with the Shapiro-Wilk and Hatley tests respectively. Data were then submitted to analysis of variance using treatment as a fixed effect. The effect of treatment was isolated using the TukeyKramer test (General Linear Model procedure).

Residual force correlation was based on likelihood and $r$ (rho) values determined using linear correlation analysis. Normal distribution of data and homogeneity of variance were confirmed; therefore, the Pearson's correlation was employed. The level of significance was set at $5 \%$.

\section{Results and Discussion}

Despite the wide availability of techniques for treatment of CCLR in dogs, not one single surgical procedure can be recommended based on evidence of return to function (ARAGON; BUDSBERG, 2005). Studies comparing biomechanical effects of different techniques have reached different conclusions and experimental protocols are not standardized. The experimental protocol in this trial was based on previously tested methods (BARRETO, 2000; MARADEI PEREIRA, 2004; ROMANO, 2006; ROMANO et al., 2006) in an effort to minimize potential method-related differences. The sample in this study comprised nine male and eleven female canine cadavers weighing $23.42 \pm 2.83 \mathrm{~kg}$. Twelve right and eight left hindlimbs were used.

The load (approximately $100 \mathrm{~N}$ ) selected for pretension of the suture loop in this study was based on the force required to tighten suture knots in clinical settings and is equivalent to the tension employed in similar CCLR studies (CAPORN; ROE, 1996; ANDERSON et al., 1998; NWADIKE; ROE, 1998; VIANNA; ROE, 2006). The use of a needle holder to hold the first throw of the knot was intended to increase initial loop tension and stiffness, without compromising suture tensile strength (CAPORN; ROE, 1996; HUBER et al., 1999).

The $100 \mathrm{~N}$ load employed in this trial is thought to reproduce the in vivo loading scenario and reflect the actual load placed on the implant postoperatively (CAPORN; ROE, 1996). However, stifle structures may with stand to loads corresponding to 10 to $25 \%$ of the maximum load to failure reported for the CCL (1279 to 2449 N; HULSE et al., 1983; JOHNSON et al., 1989; PATTERSON et al., 1991). Given the load and the number of repeated cycles required for ligament rupture cannot be determined in vivo (NWADIKE; ROE, 1998), the actual strain exerted on the CCL has not been quantified to date.

Mean residual forces documented in different experimental groups were as follows: $\mathrm{LFTS}=9.42$ $\pm 10.23 ;$ MRIT $=35.92 \pm 16.62 ;$ CCRL $=-3.90 \pm$ 5.39. Residual forces differed significantly between LFTS and CCLR, MRIT and CCLR, and LFTS and MRIT groups $(\mathrm{p}<0.01, \mathrm{p}<0.001$ and $\mathrm{p}<0.001$ respectively).

Stabilization techniques tended to generate positive (tensile) forces. Tensile forces are generated in response to articular compression and also reflected the fixation of the tibia to the distal grip leading to femoral tension in this trial. The opposite scenario was observed in the CCLR group: lack of enough stability to counteract compressive forces leading to prevalence of negative (compressive) forces. The fact that tension generated by MRIT was much higher suggests greater counteraction of compressive forces. Where residual force is concerned, only LFTS and CCLR groups were significantly correlated in this study $(r=0.5546$; $\mathrm{p}=0.0111$ ). A linear relationship between residual 
forces documented in CCLR stifles and joint stabilization following LFTS can therefore be inferred. Lack of correlation with MRIT suggests additional fabello-tibial suture does not consistently increase stifle stability.

Intact stifles served as their own controls in this study so as to mitigate the potential impact of individual differences (CHAILLEUX et al., 2007), which may exist even between stifles of the same dog. Even under physiological conditions, nylon leader lines must withstand high continuous loading cycles and may not be able to retain enough tensile strength for the time required for periarticular fibrosis to develop (CAPORN; ROE, 1996). The $100 \mathrm{~N}$ employed in this trial is well below loads involved in high-intensity physical activity (CAPORN; ROE, 1996; WEIGEL et al., 2005) and was assumed to reflect the load experienced by dogs during rest or light exercise.

The choice of knots to tie suture loops may have negatively impacted stifle biomechanics following experimental surgical repair in this trial. However, although crimp clamp systems are thought to be superior to knotted loops (ANDERSON et al., 1998; PEYCKE et al., 2002; BANWELL et al., 2005; VIANNA; ROE, 2006; CABANO et al., 2011;
MARITATO et al., 2012), the creation of localized points of stress concentration and deformation that would potentially weaken the nylon leader line is a consensus among researchers, regardless of suture methods. This hypothesis is supported by the fact that most suture failures occur at these locations (LEWIS et al., 1997; ANDERSON et al., 1998; PEYCKE et al., 2002; SICARD et al., 2002; BANWELL et al., 2005). Other potential points of stress concentration are the tibial tunnel, the fabellofemoral ligament and the fabella (ANDERSON et al., 1998). Similar weak points were not observed in this study, possibly due to the low number of cycles and the non-destructive nature of biomechanical testings performed.

Statistical findings relative to cranial/caudal drawer motion and joint stiffness in the different groups studied are given in Table 1. Caudal drawer motion did not differ significantly ( $p>0.05$ ) between CCL and other experimental groups in this study. However, numerical increases in caudal motion were observed in CCLR and LFTS groups and are coincident with previous findings of increased caudal tibial displacement following LFTS (HARPER et al., 2004). Conversely, decreased caudal drawer motion such as in the MRIT group has not been reported to date.

Table 1. Mean cranial/caudal drawer motion (CRDM and CDDM, mm), and cranial/caudal joint stiffness (CRJS and CDJS, $\mathrm{N} / \mathrm{mm}$ )values documented in different groups of stifles during biomechanical compressive tests $(100 \mathrm{~N})$, and respective $\mathrm{p}$ values.

\begin{tabular}{llllll}
\hline & CCL & CCLR & LFTS & MRIT & P \\
\hline CRDM & $3.27^{\mathrm{D}}$ & $13.09^{\mathrm{A}}$ & $5.54^{\mathrm{B}}$ & $4.27^{\mathrm{C}}$ & 0.0001 \\
CDDM & $4.02^{\mathrm{AB}}$ & $4.55^{\mathrm{A}}$ & $4.44^{\mathrm{A}}$ & $3.47^{\mathrm{B}}$ & 0.0001 \\
CRJS & $33.46^{\mathrm{A}}$ & $25.99^{\mathrm{B}}$ & $20.19^{\mathrm{C}}$ & $21.82^{\mathrm{C}}$ & 0.0001 \\
CDJS & 28.32 & 28.32 & 29.34 & 30.71 & 0.5291 \\
\hline
\end{tabular}

A,B,C,D Means with different capital superscript letters in the same row differ significantly (Tukey test; P $<0.05$ ); CCL: intact cranial cruciate ligament; CCLR: ruptured cranial cruciate ligament; LFTS: lateral fabello-tibial suture; MRIT modified retinacular imbrication technique.

In the normal stifle, the intact cruciate ligaments maintain the natural relationship between constraining structures and allow force distribution within physiological limits (HARPER et al., 2004), leading to physiological caudal displacement and axial rotation of the tibia. In CCLR, abnormal joint rotation motion and relationship between restrictive structures overload the CCL, increasing caudal 
drawer movements when compared with the intact stifle. As previously observed (ARNOCZKY et al., 1977; SELMI et al., 2003), LFTS suture changes the instant center of movement, restricting axial tibial rotation and promoting compression between the tibial and femoral articular surfaces. LFTSinduced compression forces, as well as the added tension exerted on posterolateral structures, may increase the contact between constraining stifle structures and decrease caudal drawer stifle motion, particularly following MRIT.

CCLR-related joint instability leads to microtrauma and enzymatic degradation, resulting in extracellular matrix changes such as chondroid metaplasia and loss of cellular architecture, that ultimately alter the morphology of the caudal cruciate ligament (ZACHOS et al., 2002). However, the impacts of biomechanical changes induced by the techniques employed in this study on the caudal cruciate ligament have not been described. The lack of data on potential long-term consequences of caudal cruciate ligament overload is often emphasized in tibial-plateau leveling osteotomy studies, in which this finding has been observed (WARZEE et al., 2001).

Lateral fabello-tibial suture yielded higher positive values (tensile strength) than MRIT during biomechanical trials in this study. Tensile strength may have resulted from the articular compression exerted by stabilization sutures. Also, the distal fixation of the tibia resulted in the femur being pulled in a distal direction. The opposite scenario (negative or compressive residual forces) was observed in the CCLR group. Different from the intact stifle, where the CCL stabilizes the joint, joint stability is lost following CCLR and compressive forces are generated under load.

Cranial stiffness differed significantly between groups, but not between LFTS and MRIT stifles. Greater stiffness in CCL than CCLR stifles, and in CCLR than reconstructed stifles has been previously reported (HARPER et al., 2004). In the absence of the primary constraining structure (CCL), load is distributed among the remaining constraining structures of the joint, such as collateral ligaments and meniscus, which arestiffer than the nylon leader line. The nylon leader line would therefore be expected to have greater impact on cranial drawer motion than stiffness.

Mean cranial drawer motion values (13.09 mm) documented in the CCLR group in this study were similar to values reported by Lewis et al. (1997), and Romano et al. (2006) (12.2 and $13.18 \mathrm{~mm}$ respectively). Mean cranial joint stiffness (25.99 $\mathrm{N} / \mathrm{mm}$ ) was also similar to findings by Romano et al. (2006) $(23.65 \mathrm{~N} / \mathrm{mm})$. Mean cranial drawer motion values in the LFTS group $(5.54 \mathrm{~mm})$ differed from findings by Lewis et al. (1997) (2.0 and $3.0 \mathrm{~mm}$, following the first and $12^{\text {th }}$ loading cycle respectively), meaning we started from similar baseline values but did not achieve the same degree of stability. This may have been due to operator-dependent effects or anatomical factors interfering with the degree of stabilization provided by extracapsular surgical intervention. Tibial plateau angle is one such variables, given resultant forces are directly related to tibial plateau slope (SHAHAR; MILGRAM, 2006; KOWALESKI et al., 2005); this could be one of the anatomical factors responsible for discrepancies between results of this and previous trials (LEWIS et al., 1997). Lack of control for tibial plateau slope is one of the limitations of this study.

In this study, mean cranial stiffness following LFTS $(20.19 \mathrm{~N} / \mathrm{mm})$ was similar to previously reported values $24.16 \mathrm{~N} / \mathrm{mm}$ (ROMANO et al., 2006). Mean cranial and caudal drawer motion and mean cranial and caudal joint stiffness $(4.27 \mathrm{~mm}$, $3.47 \mathrm{~mm}, 21.82 \mathrm{~N} / \mathrm{mm}$ and $30.70 \mathrm{~N} / \mathrm{mm}$ respectively) in canine stifles submitted to MRIT have not been previously reported. Findings in the MRIT group in this study introduce new data and support better outcomes with this technique compared to LFTS in regards to minimization of cranial and caudal displacement. However, cranial drawer motion was 
not detected in previous kinematic analysis of MRIT treated stifles (CHAILLEUX et al., 2007), possibly due to specific testing conditions (unloaded cadaver stifles). Despite reduced translation, both procedures achieved similar resistance; therefore similar risks of early rupture due to cyclic movement in patients should be expected regardless of the procedure employed.

Despite not having investigated the biomechanics of MRIT, Lewis et al. (1997) have reported on its routine application in clinical settings. The elimination of the support and stability provided by contracting hind limb muscles (HARPER et al., 2004) was an important limiting factor in this study. Still, similar mean cranial drawer motion values documented in intact and MRIT treated stifles in this trial support the biomechanical superiority of MRIT over LFTS. Clinical implications of the results presented remain to be determined. Kinetic gait analysis studies are warranted to determine whether this biomechanical advantage translates into improved hindlimb function in dogs. A specific method was already reported to evaluate loading bearing during kinetic gait analysis in dogs affected by CCLR using pads pressure measurements (SOUZA et al., 2014).

LFTS and MRIT increase joint stability but MRIT is more effective; however none of the techniques studied was able to restore original intact stifle stiffness.

\section{References}

ANDERSON, C. C.; TOMLINSON, J. L.; DALY, W. R.; CARSON, W. L.; PAYNE, J. T.; WAGNER-MANN C. C. Biomechanical evaluation of a crimp clamp system for loop fixation of monofilament nylon leader material used for stabilization of the canine stifle joint. Veterinary Surgery, Germantown, v. 27, n. 6, p. 533-539, 1998.

ARAGON, C. L.; BUDSBERG, S. C. Applications of evidence-based medicine: cranial cruciate ligament injury repair in the dog. Veterinary Surgery, Germantown, v. 34, n. 2, p. 93-98, 2005.
ARNOCZKY, S. P.; TORZILLI, P. A.; MARSHALL, J. L. Biomechanical evaluation of anterior cruciate ligament repair in the dogs: an analysis of the instant center of motion. Journal of the American Animal Hospital Association, Lakewood, Colorado, v. 13, p. 553-558, 1977.

BANWELL, M. N.; KERWIN, S. C.; HOSGOOD, G.; HEDLUND, C. S.; METCALF, J. B. In vitro evaluation of the 18 and $36 \mathrm{~kg}$ securos cranial cruciate ligament repair system. Veterinary Surgery, Germantown, v. 34, n. 3, p. 283-288, 2005.

BARRETO, J. M. Avaliação mecânica da fixação femoral de tendões ísquio-tibiais e do ligamento patelar com parafuso de interferência nas reconstruções do ligamento cruzado anterior. 2000. Tese (Doutorado em Ciências, Área de Ortopedia e Traumatologia) Faculdade de Medicina, Universidade de São Paulo, São Paulo.

BURGESS, R.; ELDER, S.; MCLAUGHLIN, R.; CONSTABLE, P. In vitro biomechanical evaluation and comparison of FiberWire, FiberTape, OrthoFiber, and nylon leader line for potential use during extraarticular stabilization of canine cruciate deficient stifles. Veterinary Surgery, Germantown, v. 39, n. 2, p. 208-215, 2010.

CABANO, N. R.; TROYER, K. L.; PALMER, R. H.; PUTTLITZ, C. M.; SANTONI, B. G. Mechanical comparison of two suture constructs for extra-capsular stifle stabilization. Veterinary Surgery, Germantown, v. 40, n. 3, p. 334-339, 2011.

CAPORN, T. M.; ROE, S. C. Biomechanical evaluation of the suitability of monofilament nylon fishing and leader line for extra-articular stabilisation of the canine cruciate-deficient stifle. Veterinary and Comparative Orthopaedic and Traumatology, Stuttgart, v. 9, n. 3, p. 126-133, 1996.

CHAILLEUX, N.; LUSSIER, B.; DE GUISE, J.; CHEVALIER, Y.; HAGEMEISTER, N. In vitro 3-dimensional kinematic evaluation of 2 corrective operations for cranial cruciate ligament-deficient stifle. Canadian Journal of Veterinary Research, Ottawa, v. 71, n. 3, p. 175-180, 2007.

CHOATE, C. J.; LEWIS, D. D.; CONRAD, B. P.; HORODYSKI, M. B.; POZZI, A. Assessment of the craniocaudal stability of four extracapsular stabilization techniques during two cyclic loading protocols: a cadaver study. Veterinary Surgery, Germantown, v. 42, n. 7, p. 853-859, 2013. 
D'AMICO, L. L.; LANZ, O. I.; AULAKH, K. S.; BUTLER, J. R.; MCLAUGHLIN, R. M.; HARPER, T. A.; WERRE, S. R. The effects of a novel lateral extracapsular suture system on the kinematics of the cranial cruciate deficient canine stifle. Veterinary and Comparative Orthopaedic and Traumatology, Stuttgart, v. 26, n. 4, p. 271-279, 2013.

HARPER, T. A. M.; MARTIN, R. A.; WARD, D. L.; GRANT, J. W. An in vitro study to determine the effectiveness of a patellar ligament/fascia lata graft and new tibial suture anchor points for extracapsular stabilization of the cranial cruciate ligament-deficient stifle in the dog. Veterinary Surgery, Germantown, v. 33, n. 5, p. 531-541, 2004.

HUBER, D. J.; EGGER, E. L.; JAMES, S. P. The effect of knotting method on the structural properties of large diameter nonabsorbable monofilament sutures. Veterinary Surgery, Germantown, v. 28, n. 4, p. 260-267, 1999.

HULSE, D. A.; BUTLER, D. L.; KAY, M. D.; NOYES, F. R.; SHIRES, P. K.; D'AMBROSIA, R.; SHOJI, H. Biomechanics of cranial cruciate ligament reconstruction in the dog. In vitro laxity testing. Veterinary Surgery, Germantown, v. 12, n. 3, p. 109-112, 2008.

JOHNSON, S. G.; HULSE, D. A.; HOGAN, H. A.; NELSON, J. K.; BOOTHE, H. W. System behavior of commonly used cranial cruciate ligament reconstruction autografts. Veterinary Surgery, Germantown, v. 18, n. 6, p. 459-465, 1989.

KOWALESKI, M. P.; APELT, D.; MATTOON, J. S.; LITSKY, A. S. The effect of tibial plateau leveling osteotomy position on cranial tibial subluxation: an in vitro study. Veterinary Surgery, Germantown, v. 34, n. 4, p. 332-336, jul. 2005.

LEOPIZZI, N. Estudo experimental das propriedades mecânicas do ligamento cruzado cranial de cães em diferentes graus de flexão do joelho. 1998. Dissertação de Mestrado em Ciências - Área de Ortopedia e Traumatologia, Faculdade de Medicina Veterinária e Zootecnia, Universidade de São Paulo, São Paulo.

LEWIS, D. D.; MILTHORPE, B. K.; BELLENGER, C. R. Mechanical comparison of materials used for extracapsular stabilization of the stifle joint in dogs. Australian Veterinary Journal, St Leonards, v. 75, n. 12, p. 890-896, 1997.

MARADEI PEREIRA, J. A. R. Estudo biomecânico da influência da espessura do enxerto e da técnica de dois feixes na reconstrução do ligamento cruzado posterior. 2004. Dissertação (Mestrado em Ciências, Área de Ortopedia e Traumatologia) - Faculdade de Medicina, Universidade de São Paulo, São Paulo.
MARITATO, K. C.; BARNHART, M. D.; KAZANOVICZ, A. J.; NABER, S. J. In vitro mechanical evaluation and comparison of two crimping devices for securing monofilament nylon and multifilament polyethylene for use in extracapsular stabilization of the canine stifle. Veterinary and Comparative Orthopaedic and Traumatology, Stuttgart, v. 25, n. 6, p. 466-471, 2012.

NWADIKE, B. S.; ROE, S. C. Mechanical comparison of suture material and knot type used for fabello-tibial sutures. Veterinary and Comparative Orthopaedic and Traumatology, Stuttgart, v. 11, n. 1, p. 47-52, 1998.

PATTERSON, R. H.; SMITH, G. K.; GREGOR, T. P.; NEWTON, C. D. Biomechanical stability of four cranial cruciate ligament repair techniques in the dog. Veterinary Surgery, Germantown, v. 20, n. 2, p. 85-90, 1991.

PEYCKE, L. E.; KERWIN, S. C.; HOSGOOD, G.; METCALF, J. B. Mechanical comparison of six loop fixation methods with monofilament nylon leader line. Veterinary and Comparative Orthopaedic and Traumatology, Stuttgart, v. 15, n. 4, p. 210-214, 2002.

ROMANO, L.; PEREIRA, C. A. M.; SCHMAEDECKE, A.; SAUT, J. P. E.; FERRIGNO, C. R. A. Análise biomecânica do joelho íntegro e com ruptura do ligamento cruzado cranial quanto ao grau de deslocamento cranial e rigidez articular em cães. Acta Cirúrgica Brasileira, São Paulo, v. 21, n. 1, p. 47-51, 2006.

ROMANO, L. Análise biomecânica da articulação femoro-tíbio-patelar quanto à translação cranial da tíbia em relação ao fêmur em milímetros e da técnica extra-capsular com nylon e anel de aço para reparação do ligamento cruzado cranial em cães. 2006. Dissertação (Mestrado em Ciências - Área Clínica Cirúrgica Veterinária) - Faculdade de Medicina Veterinária e Zootecnia. Universidade de São Paulo, São Paulo.

SELMI, A. L.; LINS, B. T.; BARBUDO-SELMI, G. R.; MENDES, G. M. Centro instantâneo de movimento, na avaliação ex-vivoda reconstrução extra-articularfabelotibial, após transecção do ligamento cruzado cranial em cães. Ciência Rural, Santa Maria, v. 33, n. 5, p. 875-880, 2003.

SHAHAR, R.; MILGRAM, J. Biomechanics of tibial plateau leveling of the canine cruciate-deficient stifle joint: a theoretical model. Veterinary Surgery, Germantown, v. 35, n. 2, p. 144-149, 2006.

SICARD, G. K.; HAYASHI, K.; MANLEY, P. A. Evaluation of 5 types of fishing material, 2 sterilization methods, and a crimp-clamp system for extra-articular stabilization of the canine stifle joint. Veterinary Surgery, Germantown, v. 31, n. 1, p. 78-84, 2002. 
SNOW, L. A.; WHITE, R.; GUSTAFSON, S.; XIE, L.; HOSGOOD, G.; MONROE, W. T.; CASEY, J. P.; LOPEZ, M. J. Ex vivo comparison of three surgical techniques to stabilize canine cranial cruciate ligament deficient stifles. Veterinary Surgery, Germantown, v. 39, n. 2, p. 195-207, 2010.

SOUZA, A. N.; TATARUNAS, A. C.; MATERA, J. M. Evaluation of vertical forces in the pads of Pitbulls with cranial cruciate ligament rupture. BMC Veterinary Research, London, United Kingdom, v. 10, n. 51, p. 1-6, 2014.

VASSEUR, P. B. Stifle joint. In: SLATTER, D. Textbook of small animal surgery. Philadelphia: Saunders, 2003. p. 2090-2132.

VIANNA, M. L.; ROE, S. C. Mechanical comparison of two knots and two crimp systems for securing nylon line used for extra-articular stabilization of the canine stifle. Veterinary Surgery, Germantown, v. 35, n. 6, p. 567-572, 2006.
WARZEE, C. C.; DEJARDIN, L. M.; ARNOCZKY, S. P.; PERRY, R. L. Effect of tibial plateau leveling on cranial and caudal tibial thrusts in canine cranial cruciate-deficient stifles: an in vitro experimental study. Veterinary Surgery, Germantown, v. 30, n. 3, p. 278-286, 2001.

WEIGEL, J. P.; ARNOLD, G.; HICKS, D. A.; MILLIS, D. L. Biomechanics of rehabilitation. Veterinary Clinics of North. America Small Animal Practice, Maryland Heights, v. 35, n. 6, p. 1255-1285, 2005.

WILKE, V. L.; ROBINSON, D. A.; EVANS, R. B.; ROTHSCHILD, M. F.; CONZEMIUS, M. G. Estimate of the annual economic impact of treatment of cranial cruciate ligament injury in dogs in the United States. Journal of the American Veterinary Medical Association, New York, v. 227, n. 10, p. 1604-1607, 2005.

ZACHOS, T. A.; ARNOCZKY, S. P.; LAVAGNINO, M.; TASHMAN, S. The effect of cranial cruciate ligament insufficiency on caudal cruciate ligament morphology: an experimental study in dogs. Veterinary Surgery, Germantown, v. 31, n. 6, p. 596-603, 2002. 
